\title{
A comparison of PCR-based markers for the molecular identification of Sphagnum species of the section Acutifolia
}

\author{
Jakub Sawicki*, Monika Szczecińska \\ Department of Botany and Nature Protection, University of Warmia and Mazury in Olsztyn, Plac Kódzki 1, 10-727 Olsztyn, Poland
}

\section{Abstract}

RAPDs, ISJs, ISSRs, ITS and katGs were applied to determine genetic relationships between common Sphagnum species of the section Acutifolia. Twenty populations were genotyped using ten ISJ primers, 12 pairs of kat $\mathrm{G}$ primers, 10 ISSR and 10 RAPD primers, and a restriction analysis of ITS1 and ITS2. ISSR and katG markers revealed the greatest number of species-specific bands. An analysis of ITS1 and ITS2 regions with restriction enzymes also proved to be a highly effective tool for species identification.

Keywords: Sphagnum, genetic similarity, molecular markers RAPD, ISJ, katG, ITS, ISSR

\section{Introduction}

Due to their great phenotypic plasticity, the classification of peat moss species often requires microscopic identification, which is both labor- and time-consuming. In addition to a standard morphological description, the classification of bryophytes increasingly often involves the use of molecular markers $[1,2]$. Chloroplast and nuclear genomes are mainly used, but this approach implies high analysis costs. Species-specific molecular markers support material identification even when diagnostic traits cannot be observed. The above applies mostly to traits related to sexual reproduction (gametengia, sporophytes) and vegetative reproduction (gemmae) which are often undeveloped or already degraded.

The identification of peat moss species possess some problems. According to various authors, their number ranges from 39 [3] to 340 [4]. The main reason for such a wide variation in the reported number of Sphagnum species is their high phenotypic plasticity. Mosses growing in wet habitats exhibit high morphological variability in response to water level fluctuations and changes in other environmental conditions [5]. Another factor that affects morphological variability and hinders the species classification of peat mosses is hybridization [6-9].

Isoenzymatic electrophoresis is a rapid and relatively inexpensive method of molecular species identification. The use of markers of this class permitted the molecular identification of the majority of morphologically controversial species

\footnotetext{
*Corresponding author. Email: jakub.sawicki@uwm.edu.pl

This is an Open Access digital version of the article distributed under the terms of the Creative Commons Attribution 3.0 License (creativecommons.org/licenses/ by/3.0/), which permits redistribution, commercial and non-commercial, provided that the article is properly cited.
}

of the genus Sphagnum [10,11]. However, their practical application is difficult, as in order to obtain stable and distinct isoenzymatic patterns, plants should be grown under glass-house conditions to normalize their expression levels and increase vitality [12]. Electrophoresis of enzymatic proteins cannot be applied to herbaceous materials, either, which makes it useless as a tool for verifying the correctness of species identification. Therefore, other molecular markers enabling a rapid, reliable and inexpensive identification have to be found.

PCR-based DNA analyses provided new insights into the taxonomy of peat mosses. Studies of the genus Sphagnum rely primarily on RAPD $[13,14]$, ISSR $[9,15]$ and SSR [16] markers, and ITS sequences [17,18]. With a few exceptions [19], the above markers have not been used for molecular species identification.

The objective of the present study was to evaluate the suitability of five types of DNA markers for molecular species identification. Peat moss species of the section Acutifolia were analyzed. Apart from markers that are commonly applied in studies of the genus Sphagnum, i.e. RAPD, ISSR and nuclear ITS regions, we also tested ISJ markers and primers complementary to the kat $\mathrm{G}$ gene, which had been successfully used as species-specific markers in higher plants [20] and liverworts of the genera Aneura [21], Conocephalum [22] and Pellia [23].

The nuclear ITS region, analyzed based on the polymorphism of restriction loci $[24,25]$ and a direct comparison of sequences $[18,26]$, is widely used in the taxonomic studies of bryophytes. An extensive review of ITS applications in studies of bryophytes is given by Vanderpoorten et al. [27]. In contemporary research, non-specific RAPD markers are less frequently used, mainly due to the low reproducibility of results between laboratories [28,29]. Nevertheless, they continue to provide effective species-specific markers for many taxa, and they facilitate a quick and easy identification of the studied organisms [20,21]. They have also been successfully used in studies of bryophytes [30], including peat moss species $[14,22,31,32]$. 
Owing to their non-coding character, microsatellite sequences are subject to greater mutation pressure from the remaining DNA fragments, and they display a high degree of polymorphism. In view of the above, analyses of variability in intermicrosatellite sequences (ISSR) became a useful tool for determining genetic similarity in the region of closely interrelated groups of organisms [33]. Inter-Simple Sequence Repeat (ISSR) markers demonstrate a high level of result repeatability and a high degree of polymorphism. They are characterized by high efficiency and a relatively low cost of use [34]. These markers are widely used in both taxonomic and population genetics studies of bryophytes [15,35-38].

ISJ markers, based on sequences commonly found in plants and indispensable for post-transcription DNA processing [39], are less popular. ISJ primers are partly complementary to the sequences on the exon-intron boundary. At first these primers were used in studies of vascular plants [20,40,41], but they also proved to be a useful tool in the taxonomy of bryophytes $[21,37,38]$. In addition to the above marker classes, sequences complementary to the $k a t \mathrm{G}$ gene coding the enzyme catalaseperoxidase were also used. Previous studies have shown that sequences of the kat $\mathrm{G}$ gene are highly effective species-specific markers for many taxa $[20,21,42]$. They were most effective in differentiating between twin species of the genus Conocephalum, revealing the highest number of species-specific amplification products per primer [22]. A correlation was also found between the amplification patterns of genomic DNA with $k a t \mathrm{G}$ sequences and electrophoretic peroxidase patterns in the genus Calamagrostis [43] and Lolium [44]. Peroxidases proved to be effective species-specific markers for the genus Sphagnum $[45,46]$, which additionally supported the use of the kat $\mathrm{G}$ gene sequence in this study.

The main purpose of this study was to determine the suitability of the above DNA markers for molecular species identification, based on peat mosses of the section Acutifolia.

\section{Material and methods}

\section{Plant material}

The studied material comprised four population samples of each of the following species: S. capillifolium, S. fimbriatum, $S$. girgensohnii, S. rubellum and S. russowii, collected mainly in Central Europe. The population details are given in Appendix $\mathrm{S} 1$. In the case of several populations, in vitro spore cultures were also used (Appendix S1). Each sample consisted of twenty plants randomly selected in the population. After morphological delimitation, all plants were cleaned and stored at $-20^{\circ} \mathrm{C}$.

\section{DNA extraction}

Total genomic DNA was extracted from 20 individuals from each population. DNA was isolated by the modified CTAB procedure. Details are given in previous papers [20,21]. The purity of DNA samples was assessed spectrophotometrically and reached $90-94 \%$. The DNA content of the samples was 20 $\mu \mathrm{g}$ to $35 \mu \mathrm{g}$.

\section{RAPD, ISJ and ISSR markers}

In order to minimize the negative consequences of low repeatability attributed to RAPD markers [28], each reaction was performed twice, and only bands present in both banding patterns were analyzed. The sequences of used primers used for
DNA amplification in this study are shown in Tab. 1. The PCR reaction was conducted in a volume of $20 \mu \mathrm{l}$ containing $2 \mu \mathrm{l}$ PCR buffer $\left[400 \mathrm{mM}\left(\mathrm{NH}_{4}\right)_{2} \mathrm{SO}_{4}\right.$ and $1 \mathrm{M}$ Tris- $\mathrm{HCl}, \mathrm{pH} 9$ at $25^{\circ} \mathrm{C}$ ], $2 \mathrm{mM} \mathrm{MgCl}, 200 \mu \mathrm{M}$ each dATP, dGTP, dCTP, dTTP, $0.3 \mu \mathrm{M}$ primer, 1 unit Tfl polymerase (Epicentre Technology) and $40 \mathrm{ng}$ of template DNA. The RAPD-PCR reaction was processed at $94^{\circ} \mathrm{C}$ for $4 \mathrm{~min}$ followed by 45 cycles at $94^{\circ} \mathrm{C}$ for 1 $\min , 37^{\circ} \mathrm{C}$ for $1 \mathrm{~min}$, and $72^{\circ} \mathrm{C}$ for $1.5 \mathrm{~min}$, with a final extension step of $72^{\circ} \mathrm{C}$ for $5 \mathrm{~min}$ The PCR reaction conditions for ISJ and ISSR markers were similar to those for RAPD markers, except for a higher annealing temperature at $52^{\circ} \mathrm{C}$.

\section{ITS markers}

The ITS sequences were analyzed by polymerase chain reaction-restriction fragment length polymorphism (PCRRFPL). The sequences of ITS primers used for DNA amplification in this study are given in Tab. 1 . The PCR reaction was conducted in a volume of $20 \mu \mathrm{l}$ containing $1 \mu \mathrm{l}$ PCR buffer [400 $\mathrm{mM}\left(\mathrm{NH}_{4}\right)_{2} \mathrm{SO}_{4}$ and $1 \mathrm{M}$ Tris- $\mathrm{HCl}, \mathrm{pH} 9$ at $25^{\circ} \mathrm{C}$ ], $2 \mathrm{mM}$ $\mathrm{MgCl}_{2}, 200 \mu \mathrm{M}$ each dATP, dGTP, dCTP, dTTP, $0.3 \mu \mathrm{M}$ of each primer, 1 unit Tfl polymerase (Epicentre Technology) and 40 ng of template DNA. The reaction was processed at $94^{\circ} \mathrm{C}$ for $4 \mathrm{~min}$ followed by 30 cycles at $94^{\circ} \mathrm{C}$ for $1 \mathrm{~min}, 58^{\circ} \mathrm{C}$ for $1 \mathrm{~min}$, and $72^{\circ} \mathrm{C}$ for $1.5 \mathrm{~min}$, with a final extension step of $72^{\circ} \mathrm{C}$ for 5 min. The PCR products were digested by HaeIII and TaqI endonucleases (Roche) according to the manufacturer's manual.

\section{Primers complementary to sequences of the kat $G$ gene coding catalase- peroxidase}

The PCR reaction conditions for kat $\mathrm{G}$ markers were similar to those for ITS markers, except for a lower annealing temperature at $56^{\circ} \mathrm{C}$.

\section{Electrophoresis}

PCR samples were loaded on a $2 \%$ (for ISJ, katG and RAPD markers) or 2.5\% (for ISSR and ITS) agarose gel containing 0.5 $\mu \mathrm{g} / \mathrm{ml}$ ethidium bromide and separated in $1 \mathrm{x}$ TBE buffer at 120 $\mathrm{V}$ constant power. After rinsing in deionized water, agarose gel was analyzed in a transilluminator under UV light at a wavelength of $302 \mathrm{~nm}$ with the application of the Felix 1010 system.

\section{Data analysis}

All bands that could be reliably read were treated as single dominant loci and scored either present (1) or absent (0) across all genotypes. The reproducibility of the ISJ and ISSR markers was checked by randomly selecting 10 samples and amplifying the extracted DNA twice. The error rate was calculated as the ratio between all differences and all bands comparisons in these ten duplicated ISJ-ISSR profiles [47]. Calculation of the error rate during the ISSR and ISJ bands resulted in seven differences in the 1921 comparisons, giving an error rate $0.36 \%$. Genetic diversity measured by the percentage of polymorphic bands (P) and private alleles was calculated using GenAlEx 6.1 [48]. The number of fixed allelic differences among species was estimated for all pairwise combinations of taxa using the Sites program [49].

\section{Results}

\section{PCR screen for contamination of DNA}

Algae, bacteria and fungal endophytes are common in many 
Tab. 1 Sequences of primers used in this study.

\section{ISJ}

$\begin{array}{ll}\text { ISJ-2 } & \text { 5' ACTTACCTGAGGCGCCAC 3' } \\ \text { ISJ-3 } & \text { 5' TGCAGGTCA 3' } \\ \text { ISJ-4 } & \text { 5' GTCGGCGGACAGGTAAGT 3' } \\ \text { ISJ-5 } & \text { 5' CAGGGTCCCACCTGCA 3' } \\ \text { ISJ-6 } & \text { 5' ACTTACCTGAGCCAGCGA 3' }\end{array}$

$\begin{array}{ll}\text { ISJ-7 } & \text { 5' TGCAGGTCAGGACCCT 3' } \\ \text { ISJ-8 } & \text { 5'GACCGCTTGCAGGTAAGT 3' } \\ \text { ISJ-9 } & \text { 5' AGGTGACCGACCTGCA 3' } \\ \text { ISJ-10 } & \text { 5' ACTTACCTGCATCCCCCT 3' } \\ \text { ISJ-11 } & \text { 5' TGCAGGTCAAACGTCG 3' }\end{array}$

ISSR

\begin{tabular}{|c|c|c|c|}
\hline IS807 & $5^{\prime}(\mathrm{AG}) 8 \mathrm{~T} 33^{\prime}$ & IS828 & $5^{\prime}(\mathrm{TG}) 8 \mathrm{~A} 3^{\prime}$ \\
\hline IS810 & 5’ (GA)8T 3' & IS831 & $5^{\prime}(\mathrm{ACC}) 63^{\prime}$ \\
\hline IS816 & $5^{\prime}(\mathrm{CA}) 8 \mathrm{~T} 3^{\prime}$ & IS834 & 5’ (ATG)6 3' \\
\hline IS 822 & $5^{\prime}(\mathrm{TC}) 8 \mathrm{~A} 3^{\prime}$ & IS843 & 5’ CATGGTGTTGGTCATTGTTCCA 3' \\
\hline IS 825 & 5' (AT)8G 3' & IS849 & 5’ (GGAGA)3 3’ \\
\hline
\end{tabular}

ITS

\begin{tabular}{|c|c|c|c|}
\hline ITS1-F & 5' CAAGGTTTCCGTAGGTGAAC 3' & ITS2-F & 5’ CGGATATCTTGGCTCTTG 3' \\
\hline ITS1-R & 5’ CAAGAGCCAAGATATCCG 3' & ITS2-R & 5' CCGCTTAGTGATATGCTTA 3' \\
\hline
\end{tabular}

\begin{tabular}{|c|c|c|c|}
\hline & & $a t \mathrm{G}$ & \\
\hline katG1-1 & 5' GACTACGCCCAACAGCTCC 3' & katG7-1 & 5' GCTGGAGCAGATGGGCTTG 3' \\
\hline katG1-2 & 5’ GCGATAACCCCGCAAGACC 3' & katG7-2 & 5’ ATCCACCCGCAGCGAGAG 3’ \\
\hline katG2-1 & 5’ GCGGGGTTATCGCCGATG 3’ & katG8-1 & 5’ GTCACTGACCTCTCGCTG 3' \\
\hline katG2-2 & 5’ GCCCTCGACGGGGTATTTC 3’ & katG8-2 & 5’ CGCCCATGCGGTCGAAAC 3’ \\
\hline katG3-1 & 5’ AACGGCTGTCCCGTCGTG 3’ & katG9-1 & 5' GCGAAGCAGATTGCCAGCC 3' \\
\hline katG3-2 & 5’ GTCGTGGATGCGGTAGGTG 3' & katG9-2 & 5’ ACAGCCACCGAGCACGAC 3’ \\
\hline katG4-1 & 5’ TCGACTTGACGCCCTGACG 3’ & $k a t \mathrm{G} 10-1$ & 5' CAAAGTGTCCTTCGCCGACC 3' \\
\hline katG4-2 & 5’ CAGGTCCGCCCATGAGAG 3’ & katG10-2 & 5' CACCTACCAGCACCGTCATC 3' \\
\hline katG5-1 & 5' CGACAACGCCAGCTTGGAC 3' & katG11-1 & 5' TGCTCGACAAGGAGAACCTG 3' \\
\hline katG5-2 & 5’ GGTTCACGTAGATCAGCCCC 3’ & $k a t \mathrm{G} 11-2$ & 5’ TCCGAGTTGGACCCGAAGAC 3 \\
\hline katG6-1 & 5’ GCAGATGGGGCTGATCTACG 3’ & katG12-1 & 5’ TACCAGGGCAAGGATGGCAG 3' \\
\hline katG6-2 & 5’ ACCTCGATGCCGCTGGTG 3’ & katG12-2 & 5’ GCAAACACCAGCACCCCG 3' \\
\hline
\end{tabular}

RAPD

$\begin{array}{llll}\text { OPB-01 } & \text { 5' GTTTCGCTCC 3' } & \text { OPB-18 } & \text { 5' CCACAGCAGT 3' } \\ \text { OPB-02 } & \text { 5' TGATCCCTGG 3' } & \text { OPB-19 } & \text { 5' ACCCCCGAAG 3' } \\ \text { OPB-04 } & \text { 5' GGACTGGAGT 3' } & \text { OPB-20 } & \text { 5' GGACCCTTAC 3' } \\ \text { OPB-14 } & \text { 5' TCCGCTCTGG 3' } & \text { OPD-05 } & \text { 5' TGAGCGGACA 3' } \\ \text { OPB-17 } & \text { 5' AGGGAACGAG 3' } & \text { OPD-07 } & \text { 5' TTGGCACGGG 3' }\end{array}$

bryophytes and DNA extractions from plants may sometimes produce a mixture of plant, fungal, algal and bacterial DNA. Unfortunately these endophytes cannot be removed by surface sterilization. Therefore, we first screened all extractions for the presence of fungal or algal DNA by ITS region PCR. All reactions produced amplicons with a length between 650 and 700 bp, which is similar to the lengths obtained in Sphagnum [18]. However, ten out of 50 reactions included also shorter (350$450 \mathrm{bp}$ ) amplicons and these samples were excluded from further analysis. Surface-disinfected samples representing natural peat moss populations were compared with in vitro spore cultures of those populations. If a band absent in in vitro cultures was present in field samples, amplicons of this length found in any samples were excluded from further analysis. A total of 27 bands revealed by markers of three categories ( kat $\mathrm{G}-12$,
RAPD - 10, ISSR - 5) were excluded.

\section{Efficiency of primers}

An analysis of 40 populations of five peat moss species of the section Acutifolia, performed using 22 primers representing five marker categories, enabled to distinguish 497 bands. The greatest number of bands, 162, were amplified by 12 pairs of primers complementary to the sequence of the bacterial kat $\mathrm{G}$ gene (13.5 bands per primer on average). From among kat $\mathrm{G}$ primers, katG-12 (19 bands), katG-1 and katG-5 (18 bands each) were most efficient, while katG-6 (9 bands) and katG-8 (10 bands) were least efficient. Non-specific RAPD primers revealed a total of 112 loci (11.2 per primer on average). Their efficiency ranged from 7 (OPB-3) to 17 (OPB-17) bands. Semi-specific ISJ markers amplified a total of 77 loci (10.1 on 
average). ISJ-8 was most efficient (16 loci), and least efficient were ISJ-2, ISJ-5 (8 loci each) and ISJ-6 (7 loci). Microsatellite ISSR markers revealed a total of 117 loci (11.7 bands per primer on average). ISSR-843 was characterized by the highest efficiency (17 bands), whereas the lowest number of bands (7) was revealed by ISSR-832. A restriction analysis of ITS1 and ITS2 sequences with the enzymes HaeIII and TaqI allowed to distinguish a total of 29 restriction sites (bands). The digestion of amplified ITS2 sequence with HaeIII revealed 8 bands, while the remaining combinations of sequences and enzymes permitted the identification of 7 restriction sites each.

\section{Polymorphism of DNA markers}

All of the applied DNA markers were found to be polymorphic with respect to the examined taxa of the section Acutifolia. A total of 506 bands were generated, of which $91.30 \%$ were polymorphic. RAPD markers showed a high degree of polymorphism. Their analysis enabled to identify only three monomorphic loci, i.e. $2.68 \%$ of all RAPD bands. OPB-1, OPB-20 and OPD-5 primers amplified one monomorphic locus each. Kat $\mathrm{G}$ primers revealed polymorphism in $96.4 \%$ of the amplified bands. In this category of markers, the most monomorphic bands were revealed by katG- 6 primers which amplified three bands present in all analyzed populations. Two monomorphic bands were revealed by kat G-5, and one by katG-11. Semi-specific ISJ markers exhibited an only slightly lower degree of polymorphism, with $5.19 \%$ monomorphic loci. ISJ-4 and ISJ- 8 primers revealed two monomorphic loci each. A restriction analysis of ITS1 and ITS2 sequences indicated a lower degree of polymorphism. $79.31 \%$ polymorphic bands were identified within those sequences with the use of restriction enzymes, HaeIII and TaqI. ISSR markers showed the lowest degree of polymorphism, which was determined in 92 out of 117 loci, i.e. $78.63 \%$ of all amplified ISSR bands.

\section{Species-specific markers}

The applied DNA markers revealed a total of 57 speciesspecific bands. Bands occurring only within a given species and showing no polymorphism at the intra-specific level were considered to be species-specific markers. From among the applied types of markers, $k a t \mathrm{G}$ primers, which revealed 15 bands, were found to be most effective in the molecular identification of Sphagnum species (Tab. 2). KatG-1 primers revealed 3 species-specific bands, while two bands were amplified by katG-2, katG-5, katG-7 and katG-9. KatG-4, katG-6, katG-8 and $k a t \mathrm{G}-12$ primers revealed one band each. ISSR markers revealed a total of 14 species-specific bands. Three speciesspecific bands were amplified by ISSR-816, ISSR-828 and ISSR828. Two marker amplicons were amplified by ISSR-807 and ISSR-810, whereas one such a band was revealed by ISSR- 834 . RAPD markers were only somewhat less efficient in the identification of Sphagnum species. Four species-specific loci were revealed by OPB-17, three loci - by OPD-5, and two loci - by OPB-19. OPB-1, OPB-3, OPB-14 and OPB-20 primers revealed one species-specific locus each. Non-specific RAPD markers revealed a total of 13 marker loci. Semi-specific ISJ markers revealed 10 species-specific loci, of which three were revealed by ISJ-7, two by ISJ-4, ISJ-6 and ISJ-8, and one locus - by ISJ-3.

ITS sequences were also highly efficient with respect to molecular species identification. Among 27 analyzed restriction loci, 5 were unique to one of the investigated species only. An analysis of ITS1 and ITS2 sequences with the restriction enzyme HaeIII was found to be a highly effective tool in this case,
Tab. 2 Total number of species-specific markers identified in the analyzed Sphagnum species.

\begin{tabular}{lcccccc} 
Species & RAPD & ISJ & ITS & katG & ISSR & Total \\
\hline S. fimbriatum & 1 & 3 & 1 & 5 & 3 & 13 \\
S. girgensohnii & 0 & 0 & 2 & 0 & 4 & 6 \\
S. russowii & 2 & 1 & 0 & 1 & 0 & 4 \\
S. rubellum & 5 & 4 & 1 & 5 & 3 & 18 \\
S. capillifolium & 5 & 2 & 1 & 4 & 4 & 16 \\
Total & 13 & 10 & 5 & 15 & 14 & 57 \\
& & & & & & \\
\hline
\end{tabular}

since it revealed 4 species-specific bands. Only one species-specific marker was identified based on the other enzyme, TaqI.

Apart from the number of revealed species-specific markers, another important consideration is the ratio between them and the total number of amplified bands. The highest ratio between species-specific bands and amplified bands was reported for ITS markers (0.172). As regards the remaining markers, this ratio was substantially lower, i.e. $0.130,0.120$ and 0.116 for ISJ, ISSR and RAPD markers respectively. The lowest ratio between the number of species-specific markers and the total number of amplified bands (0.076) was noted for kat $\mathrm{G}$ primers, although they revealed the greatest number of species-specific bands.

Among the studied peat moss species, the highest number of marker bands were noted for S. rubellum. A total of 18 species-specific bands were distinguished, of which five were revealed by RAPD markers (OPB-14, OPB-17, OPB20 and $\mathrm{OPD}-5$ ), katG markers (katG-1, katG-2, katG-7 and katG-12) and four by semi-specific ISJ markers (ISJ-3, ISJ-6, ISJ-7 and ISJ-8), three - by ISSR markers (ISSR-807, ISSR-828, ISSR-843) and one - by a restriction analysis of the ITS1 sequence with HaeIII. The molecular identification of S. capillifolium was carried out based on 16 bands. Similarly as in the case of $S$. rubellum, RAPD markers (OPB1, OPB-17, OPB-19 and OPD-5) revealed five species-specific loci, while katG, ISSR, ISJ and ITS markers amplified four (katG-1, katG-2, katG-5, katG-9), four (ISSR-810, ISSR-816 - two species-specific bands, ISSR-828), two (ISJ-4 and ISJ-7) and one (ITS1-HaeIII) species-specific band. As regards the molecular identification of $S$. fimbriatum, kat $\mathrm{G}$ primers were found to be most efficient, as they revealed five out of 13 species-specific markers. Both ISJ and ISSR primers amplified three species-specific bands (ISJ-4, ISJ-6 and ISJ-7; ISSR-810, ISSR-816 and ISSR-843). RAPD (OPB-3) and ITS (ITS1-TaqI) markers amplified one species-specific band. Only six marker bands were generated for S. girgensohnii. Four species-specific bands were amplified by ISSR primers (ISSR-807, ISSR-828 and ISSR-843 - two species-specific bands), and the remaining two were revealed by a restriction analysis of the ITS2 sequence with the enzyme HaeIII. Only four species-specific bands were recorded for S. russowii. Two of them were revealed by RAPD markers (OPB-17 and OPD-5), one by ISJ primers (ISJ-8) and one by kat $\mathrm{G}$ primers (katG-9). The lowest number of marker bands (4) were found for S. russowii.

\section{Differences between species pairs}

The applied markers were highly efficient in the determination of differences between pairs of species. The lowest number of fixed allelic differences was noted for S. fimbriatum and $S$. girgensohnii (Tab. 3). These two species were best distinguished 
with the use of ISSR markers ( 15 bands) and kat G primers (12 bands). A slightly higher number of differences were found between S. rubellum and S. russowii. Again, ISSR and katG markers proved most effective in their identification, revealing 19 and 12 bands respectively. The greatest number of fixed allelic differences were observed for S. fimbriatum and S. rubellum (130), and S. fimbriatum and S. capillifolium (125). The highest number of bands (249) enabling to differentiate between the analyzed pairs of species were revealed by ISSR markers. Two hundred and thirty-seven such bands were amplified by kat $\mathrm{G}$ markers.

Tab. 3 Fixed allelic differences.

\begin{tabular}{|c|c|c|c|c|c|c|}
\hline Species pair & RAPD & ISJ & ISSR & katG & ITS & Total \\
\hline S. fimbriatum & 9 & 5 & 15 & 12 & 5 & 46 \\
\hline \multicolumn{7}{|c|}{ vs. S.girgensohnii } \\
\hline S. fimbriatum & 17 & 14 & 21 & 31 & 14 & 97 \\
\hline \multicolumn{7}{|l|}{ vs. S.russowii } \\
\hline S. fimbriatum & 27 & 22 & 36 & 30 & 15 & 130 \\
\hline \multicolumn{7}{|l|}{ vs. S. rubellum } \\
\hline S. fimbriatum & 27 & 18 & 36 & 31 & 13 & 125 \\
\hline \multicolumn{7}{|c|}{ vs. S. capillifolium } \\
\hline S. girgensohnii & 8 & 6 & 18 & 25 & 17 & 74 \\
\hline \multicolumn{7}{|l|}{ vs. S. russowii } \\
\hline S. girgensohnii & 17 & 13 & 32 & 28 & 18 & 108 \\
\hline \multicolumn{7}{|l|}{ vs. S. rubellum } \\
\hline S. girgensohnii & 21 & 10 & 32 & 25 & 14 & 102 \\
\hline \multicolumn{7}{|c|}{ vs. S. capillifolium } \\
\hline S. russowii & 10 & 7 & 19 & 12 & 1 & 49 \\
\hline \multicolumn{7}{|l|}{ vs. S. rubellum } \\
\hline S. russowii & 15 & 10 & 24 & 23 & 5 & 77 \\
\hline \multicolumn{7}{|c|}{ vs. S. capillifolium } \\
\hline S. rubellum & 16 & 11 & 16 & 20 & 6 & 69 \\
\hline \multicolumn{7}{|c|}{ vs. S. capillifolium } \\
\hline Total & 167 & 116 & 249 & 237 & 108 & 877 \\
\hline
\end{tabular}

\section{Discussion}

Due to high phenotypic variation, peat moss species are a bryophyte group which is difficult to identify. The taxonomic distinctness of many species of the genus Sphagnum is often questioned, as the ranges of variation of their diagnostic traits often overlap. The use of isoenzymatic electrophoresis in a study of peat mosses often supports the validation of the taxonomic status of contentious species $[6,10,11]$. Despite their numerous advantages, such as low cost, ease and simplicity of analysis, isoenzymatic markers also have a number of limitations. To obtain stable enzymatic patterns, the studied material has to regain its vigor in the culture as field collected samples are frequently poorly developed. Selected enzymatic systems were fit for analysis only after several months of cultivation, as the collected field material display low isoenzymatic activity [12]. Isoenzymatic markers have also been useless in the analysis of herbaceous material.

DNA markers are free of the above difficulties, and they can be successfully used in taxonomic research. From among the marker classes applied in this study, kat $\mathrm{G}$ markers which are complementary to the catalase-peroxidase gene sequence proved to be most effective in the molecular identification of species of the section Acutifolia. Catalase and peroxidase participate in the molecular defense system against reactive oxygen species. The enzyme catalase-peroxidase belongs to the same group that covers peroxidase and cytochrome $c$. In all Eucaryotes, enzymes have a long homologous region which is also present in catalase-peroxidase [50].

Peroxidases as isoenzymatic markers facilitated the molecular identification of species of the section Sphagnum: S. centrale, S. magellanicum and S. palustre which are difficult to classify under certain habitat conditions [51]. From among the applied enzymatic systems in bryophytes, peroxidases proved to be highly effective species-specific markers [52]. In addition to the above peat moss species, those enzymes supported the molecular identification of four species of the section Subsecunda: S. contortum, S. denticulatum, S. inundatum and S. subsecundum [11]. Characteristic patterns of cathodic peroxidase bands were also determined for S. girgensohnii [45] and S. russowii [46]. Those enzymes also supported the identification of S. capillifolium and S. rubellum [6] with a high degree of probability.

A correlation between the products of amplification with $k a t \mathrm{G}$ primers and the electrophoretic phenotypes of peroxidase was determined in grass species of the genus Lolium [44] and in Calamagrostis arundinacea [43]. In the group of 15 species-specific kat $\mathrm{G}$ bands, the highest number was observed in S. fimbriatum and S. capillifolium (5 each), while no marker bands were determined for S. girgensohnii which could point to a high degree of peroxidase variability in this species [45]. $k a t \mathrm{G}$ sequences were also effectively used as species-specific markers and section markers in a study of the genera Polygonatum [20] and Aneura [21]. In addition to a high number of revealed marker bands, this class of markers also delivered other advantages, such as a relatively short time of analysis and a high specificity of reaction. This marker class is also less demanding as regards the quality of matrix DNA and analytical reagents.

ISSR markers were also characterized by high effectiveness in the molecular identification of the studied peat moss species, revealing a total of 14 species-specific bands. They revealed species-specific bands for all analyzed taxa, except for the allopolyploidal S. russowii. ISSR markers had been previously used in taxonomic and population studies of peat moss species $[9,15]$. Contrary to the ITS sequences popularly applied in taxonomic research, ISSR markers supported the molecular identification of species of the genus Rhytidiadelphus [35]. Microsatellite markers also supported the molecular identification of peat moss species of the section Subsecunda, while the analysis of nuclear and chloroplast genes showed no significant differences at the interspecific level [16].

Non-specific RAPD demonstrated only a slightly lower level of effectiveness in the molecular identification of the analyzed Sphagnum species (Tab. 3). Similarly to kat $\mathrm{G}$ markers, the applied RAPD primers failed to reveal a species-specific band for S. girgensohnii. Markers of this class were highly effective in distinguishing between the morphologically similar S. capillifolium and S. rubellum species, revealing five species-specific bands for each. RAPD markers were also successfully used in identifying the species of the genus Fossombronia [30] as well as the sibling species of Marchantia polymorpha [53]. RAPD markers are often criticized for low replicability [28,29]. In an attempt to obtain reproducible results in this study, the primer annealing temperature was increased and high quality reagents were used. The purity of DNA isolated by the modified CTAB 
method was also an important consideration [22].

Semi-specific ISJ markers also revealed species-specific bands. Similarly to the classes discussed above, ISJ markers also failed to reveal marker bands for S. girgensohnii. The highest number of species-specific loci was revealed in S. fimbriatum (3) and S. rubellum (4). Markers of this class are not commonly used in taxonomic studies, but they proved to be effective species-specific markers in a study of Aneura [21], Conocelphalum [54], Pellia [23] and Polygonatum [20]. The greatest advantages delivered by ISJ markers include high specificity and lower demand as regards the quality of reagents and matrix DNA in comparison with RAPD markers. Primers complementary to the sequence on the exon-intron boundary are also capable of amplifying DNA fragments containing functional genes. The above renders them a highly useful tool in conservation genetics research [26].

ITS sequences proved to be effective in the molecular identification of species of the section Acutifolia. An analysis of amplified ITS1 and ITS2 sequences involving restriction enzymes facilitated the identification of all studied taxa, revealing a minimal degree of polymorphism. The main strengths of this class of markers are low demand as regards the quality of matrix DNA, which is a very important consideration in herbaceous material analyses, and high reaction specificity. The greatest weaknesses of this marker class include longer analysis time and the need to use restriction enzymes which increase procedural costs. ITS sequences are generally used in taxonomic studies of bryophytes, but the majority of applications involve sequencing [17-19] rather than a restriction analysis [22,24,25].

The results of this study do not support equivocally of an optimal marker type for the molecular identification of the investigated species. As regards the species marked by clear genetic differences, such as $S$. fimbriatum and S. capillifolium, satisfactory results were produced by analyses involving each of the tested markers. As yet, in reference to the closely interrelated species of S. fimbriatum and S. girgensohnii, speciesspecific bands were revealed only by ITS and ISSR markers. It should be noted that the sequence analysis of several nuclear and chloroplast regions did not show any fixed nucleotide differences between those species [18]. A small number of species-specific bands for S. russowii could be attributed to the allopolyploid character of this species, which probably followed from the hybridization of S. girgensohnii and S. rubellum [10]. ISSRs could be regarded as optimal identification markers for most species owing to a high number of the revealed species-specific bands and analytical simplicity. ITS markers could offer a satisfactory alternative when herbaceous material is examined.

\section{Acknowledgements}

We thank the anonymous reviewer for helpful commentary and corrections on the manuscript.

\section{Supplementary material}

The following supplementary material for this article is available online at https://pbsociety.org.pl/journals/index.php/ asbp/rt/suppFiles/asbp.2011.017/116:

1. Appendix S1. Locality of analysed populations.

\section{References}

1. Goffinet B, Buck WR, Wall MA. Orthotrichum freyanum (Orthotrichaceae), a new epiphytic moss from Chile. Nova Hedw. 2007;131:1-11.

2. Plášek V, Sawicki J, TrávnÍčková V, Pasečná M. Orthotrichum moravicum (Orthotrichaceae), a new moss species from the Czech Republic. Bryologist. 2009;112(2):329-336. doi:10.1639/0007-2745-112.2.329.

3. Andrews AL, Britton EG, Emerson JT. Sphagnales - Bryales, Sphagnaceae/Andreaeaceae/Archidiaceae, Bruchiaceae, Ditrichaceae, Bryoxiphiaceae, Seligeriaceae. New York: New York Botanical Garden Pr Dept; 1913. (North American Flora, Series 1; vol 15).

4. Warnstorff C. Sphagnales-Sphagnaceae (Sphagnologia Universalis). Leipzig: Verlag von Wilhelm Engelmann; 1911. (Das Pflanzenreich; vol 42).

5. Hedenäs L. On the interdependence of some leaf characters within the Drepanocladus aduncus-polycarpus complex. J Bryol. 1996;19:311-324.

6. Cronberg N. Population structure and interspecific differentiation of the peat moss sister species Sphagnum rubellum and S. capillifolium (Sphagnaceae) in northern Europe. Plant Syst Evol. 1998;209(3-4):139-158. doi:10.1007/ BF00985226.

7. Cronberg N, Natcheva R. Hybridization between the peat mosses, Sphagnum capillifolium and S. quinquefarium (Sphagnaceae, Bryophyta) as inferred by morphological characters and isozyme markers. Plant Syst Evol. 2002;234(1-4):53-70. doi:10.1007/s00606-002-0196-y.

8. Flatberg K, Thingsgaard K, Såstad S. Interploidal gene flow and introgression in bryophytes: Sphagnum girgensohnii $\times$ S. russowii, a case of spontaneous neotriploidy. J Bryol. 2006;28:27-37. doi:10.1179/174328206X90459.

9. Natcheva R, Cronberg N. Recombination and introgression of nuclear and chloroplast genomes between the peat mosses, Sphagnum capillifolium and Sphagnum quinquefarium. Mol Ecol. 2007;16(4):811-818. doi:10.1111/j.1365-294X.2006.03163.x.

10. Cronberg N. Isozyme evidence of relationships within Sphagnum sect. Acutifolia (Sphagnaceae, Bryophyta). Plant Syst Evol. 1996;203(1-2):41-64. doi:10.1007/BF00985236.

11. Krzakowa M, Melosik I, editors. The variability in Polish populations of Sphagnum taxa (Subsecunda section), according to morphological, anatomical and biochemical traits. Poznań: Bogucki Wydawnictwo Naukowe. 2000.

12. Cronberg N. Isozyme electrophoresis of Sphagnum: an analysis of methodology. Lindbergia. 1995;20(1):40-48.

13. Stenøien HK, Såstad SM. Genetic structure in three haploid peat mosses (Sphagnum). Heredity. 1999;82(4):391400. doi:10.1038/sj.hdy.6884940.

14. Stenøien HK, Flatberg KI. Genetic variability in the rare Norwegian peat moss Sphagnum troendelagicum. Bryologist. 2000;103(4):794-801.

15. Gunnarsson U, Hassel K, Söderström L. Genetic structure of the endangered peat moss Sphagnum angermanicum in Sweden: a result of historic or contemporary processes? Bryologist. 2005;108(2):194-203. doi:10.1639/0007-2745(2005)108[0194:GSOTEP]2.0.CO;2.

16. Karlin EF, Boles SB, Shaw AJ. Resolving boundaries between species in Sphagnum section Subsecunda using microsatellite markers. Taxon. 2008;57:1189-2E.

17. Shaw AJ. Phylogeny of the Sphagnopsida based on 
chloroplast and nuclear DNA sequences. Bryologist. 2000;103(2):277-306.

18. Shaw AJ, Cox CJ, Boles SB. Phylogeny, species delimitation, and recombination in Sphagnum section Acutifolia. Syst Botany. 2005;30(1):16-33. doi:10.1600/0363644053661823.

19. Shaw AJ, Cox CJ. Variation in "biodiversity value" of peatmoss species in Sphagnum section Acutifolia (Sphagnaceae). Am J Bot. 2005;92(11):1774-1783. doi:10.3732/ ajb.92.11.1774.

20. Szczecińska M, Sawicki J, Polok K, Hołdyński C, Zieliński R. Comparison of three Polygonatum species from Poland based on DNA markers. Ann Bot Fennici. 2006;43:379-388.

21. Bączkiewicz A, Sawicki J, Buczkowska K, Polok K, Zieliński R. Application of different DNA markers in studies on cryptic species of Aneura pinguis (Jungermanniopsida, Metzgeriales). Crypt Bryol. 2008;29(1):3-21.

22. Sawicki J, Zieliński R. Phylogenetic relationships between five Sphagnum species of the section Acutifolia based on DNA markers. Cas Slez Muz (A). 2008;57:259-264.

23. Polok K, Sawicki J, Kubiak K, Szczecińska M, Korzekwa K, Szandar K, et al. Evolutionary divergence within Pellia endiviifolia (Dicks.) Dum. from Poland. In: Prus-Głowacki W, Pawlaczyk E, editors. Variability and evolution - new perspectives. Poznań: Adam Mickiewicz University; 2005. p. 241-252.

24. Fiedorow P, Odrzykoski IJ, Szweykowska-Kulińska Z. Phylogenetic studies of liverworts using molecular biology techniques. Scientific Publications of the University of Silesia. 1998;1696:244-249.

25. Patterson E, Boles SB, Brook AJ. Nuclear ribosomal DNA variation in Leucobryum glaucum and L. albidum (Leucobryaceae): a preliminary investigation. Bryologist. 1998;101(2):272-277. doi:10.2307/3244204.

26. Sawicki J, Plášek V, Szczecińska M. Molecular evidence does not support the current division of Orthotrichum subgenus Gymnoporus. Plant Syst Evol. 2009;279(1-4):125-137. doi:10.1007/s00606-009-0153-0.

27. Vanderpoorten A, Goffinet B, Quandt D. Utility of the internal transcribed spacers of the 18S-5.8S-26S nuclear ribosomal DNA in land plant systematics with special emphasis on Bryophytes. In: Sharma AK, Sharma A, editors. Plant genome biodiversity and evolution: Lower groups. Enfield: Science Publishers; 2006. p. 385-407. (vol 2B).

28. Vekemans X, Jacquemart A. Perspectives on the use of molecular markers in plant population biology. Belg J Bot. 1997;129(2):91-100.

29. Pérez T, Albornoz J, Domínguez A. An evaluation of RAPD fragment reproducibility and nature. Mol Ecol. 1998;7(10):1347-1357.

30. Scott KM, Crandall-Stotler B. RAPD polymorphism as an indicator of population structure, breeding system, and speciation in Fossombronia. Bryologist. 2002;105(2):225-232.

31. Såstad SM, Flatberg KI, Cronberg N. Electrophoretic evidence supporting a theory of allopolyploid origin of the peatmoss Sphagnum jensenii. Nord J Bot. 1999;19(3):355362. doi:10.1111/j.1756-1051.1999.tb01127.x.

32. Såstad SM, Stenøien HK, Flatberg KI, Bakken S. The narrow endemic Sphagnum troendelagicum is an allopolyploid derivative of the widespread $S$. balticum and $S$. tenellum. Syst Botany. 2001;26(1):66-74. doi:10.1043/0363-6445-26.1.66.

33. Zietkiewicz E, Rafalski A, Labuda D. Genome fingerprinting by simple sequence repeat (SSR)-anchored polymerase chain reaction amplification. Genomics.
1994;20(2):176-183. doi:10.1006/geno.1994.1151.

34. Kantety RV, Zeng X, Bennetzen JL, Zehr BE. Assessment of genetic diversity in dent and popcorn (Zea mays L.) inbred lines using inter-simple sequence repeat (ISSR) amplification. Mol Breeding. 1995;1(4):365-373. doi:10.1007/ BF01248414.

35. Vanderpoorten A, Hedenäs L, Jacquemart A. Differentiation in DNA fingerprinting and morphology among species of the pleurocarpous moss genus, Rhytidiadelphus (Hylocomiaceae). Taxon. 2003;52(2):229-236. doi:10.2307/3647391.

36. Spagnuolo V, Terracciano S, Cobianchi RC, Giordano S. Taxonomy of the Hypnum cupressiforme complex in Italy based on ITS and trn L sequences and ISSR markers. J Bryol. 2008;30:283-289. doi:10.1179/174328208X300750.

37. Sawicki J, Plášek V, Szczecińska M. Molecular studies resolve Nyholmiella (Orthotrichaceae) as a separate genus. J Syst Evol. 2010;48(3):183-194. doi:10.1111/j.1759-6831.2010.00076.x.

38. Plášek V, Sawicki J. Is the hairy vaginula an diagnostic feature in the taxonomy of the genus Orthotrichum. Acta Soc Bot Pol. 2010;79(1):73-80.

39. Weining S, Langridge P. Identification and mapping of polymorphisms in cereals based on the polymerase chain reaction. Theoret Appl Genetics. 1991;82(2). doi:10.1007/ BF00226215.

40. Szczecinska M, Sawicki J, Wasowicz K, Holdynski C. Genetic variation of the relict and endangered population of Chamaedaphne calyculata (Ericaceae) in Poland. Dendrobiology. 2009;62:23-33.

41. Song W, Henry RJ. Molecular analysis of the DNA polymorphism of wild barley (Hordeum spontaneum) germplasm using the polymerase chain reaction. Genet Resour Crop Evol. 1995;42(3):273-280. doi:10.1007/BF02431262.

42. Zieliński R, Polok K. Molecular evolution and plant taxonomy. In: Prus-Głowacki W, Pawlaczyk E, editors. Variability and evolution. Poznań: Adam Mickiewicz University; 2005. p. 37-56.

43. Krzakowa M, Pietkiewicz J, Polok K. Polimorfizm sekwencji genu kat $\mathrm{G}$ u Calamagrostis arundinacea (L.) Roth. In: Jackowiak B, Celka Z, editors. Taksonomia, chorologia i ekologia roślin w dobie zagrożenia różnorodności biologicznej. Materiały konferencji naukowej dedykowanej Profesorowi dr hab. Waldemarowi Żukowskiemu z okazji 70-lecia urodzin. Poznań: Adam Mickiewicz University Faculty of Biology - Department of Plant Taxonomy; 2005.

44. Polok K. Molecular evolution of the genus Lolium L. Olsztyn: Studio poligrafii komputerowej SQL; 2007.

45. Krzakowa M, Klama H, Wojtuń B. Interpopulation peroxidase variability in Sphagnum girgensohnii Russ. J Bryol. 1992;17(1):27-33.

46. Krzakowa M, Okonkwo N, Wojtuń B. Intraspecific diversity of Sphagnum russowii (Musci, Sphagnaceae) as revealed by peroxidase electrophoresis. Fragm Flor Geobot. 1995;40:447-451.

47. Pompanon F, Bonin A, Bellemain E, Taberlet P. Genotyping errors: causes, consequences and solutions. Nat Rev Genet. 2005;6(11):847-859. doi:10.1038/nrg1707.

48. Peakall R, Smouse PE. Genalex 6: genetic analysis in Excel. Population genetic software for teaching and research. Mol Ecol Notes. 2006;6(1):288-295. doi:10.1111/j.1471-8286.2005.01155.x.

49. Hey J, Wakeley J. A coalescent estimator of the population recombination rate. Genetics. 1997;145(3):833-846. 
50. Zamocky M, Janecek S, Koller F. Common phylogeny of catalase-peroksydases and ascorbate peroxidases. Gene. 2000;256:169-182.

51. Krzakowa M, Melosik I, Hansjorg R. The taxonomic status of Sphagnum centrale (Musci, Sphagnaceae) as revealed by peroxidase diversity in relation to $S$. magellanicum and $S$. palustre. Fragm Flor Geobot. 1995;40:437-446.

52. Krzakowa M. The significance of cathodic peroxidases in the taxonomy of bryophytes. In: Welinder KG, Rasmussen SK, Panel C, Grepin H, editors. Plant peroxidases: biochemistry and physiology. Geneva: University of Copenhagen, University of Geneva; 1993. p. 213-219.

53. Boisselier-Dubayle MC, Jubier MF, Lejeune B, Bischler $\mathrm{H}$. Genetic variability in the three subspecies of Marchantia polymorpha (Hepaticae): isozymes, RFLP and RAPD markers. Taxon. 1995;44(3):363-376. doi:10.2307/1223406.

54. Sawicki J, Nadolski R, Hościk M, Zieliński R. Identification of Conocephalum conicum and C. salebrosum (Hepaticophyta) based on DNA markers. Cas Slez Muz (A). 2008;57:63-80. 